\title{
FOREIGN INVESTMENT, LOANS AND ASSISTANCE IN MONGOLIAN DEVELOPMENT
}

\section{A.Buyantogs*}

Mongolian has chosen market economy and has been already conducting ten years economic reforms towards market economy. factors:

Any country's development concept is based on the following

Natural resources population

Foreign direct investment

Foreign factors, foreign investment, loans and grants have a specific importance in development of Mongolian economy. As further these factors will be the fundamentals for making economic structural changes and development, and for international labor integration.

In the concept of "Ger" of Mr. Luvsandorj, our well-known economist, academician, it is said, that the model of Mongolian national economy during the transition period from the centrally planned economy to market economy, should be based on reforms combining state regulation with market economy mechanism, to give priority to develop export oriented production, secure country's political stability, increase food-stuffs production; obtaining productivity of livestock and natural resources, and based on intelligence, belief and diligence, putting the human being above all.

If economic structural changes have been made correctly, economic growth is evident.

First of all, comparative advantages of Mongolian economy are natural resources and agriculture, particularly, livestock products. If we base on these advantages only, Mongolia will remain a developing country. So, we should make an effort to use the theory of creating new comparative advantages in practice.

The following table is the definite stages of economic structural development:

The table shows agriculture, I - industry, S - service

* A.BUYANTOGS is senior researcher at the Institute of International Studies, Mongolian Academy of Sciences. 
Table. Economic sector development (unit: percentage to national income)

Sources: P. Luvsandorj "Ger" concept

This table shows that Mongolia being an agricultural country by 1940 transferred to industrial, service, agricultural country by 1990. (From model AIS to model ISA).

However, during the transition period due to economic crisis, economic growth declined and the economy returned to the ISA model again. Therefore, in the coming years, along with the strategy of balancing development of industry, service and agriculture sectors, on the basis of the country's geographic location, wide territory, clean environment it is important to develop tourism sector and set up economic free zones.

Mongolia being located between Russia and China should have a development strategy based on requirements of the two countries' markets. Therefore, it is important to set up economic free zones in the potential areas, to process mineral and agricultural products, particularly, products of livestock, to produce final products, to give priority to develop export-oriented enterprises.

Setting up economic free zones will lead to increase of foreign investment to the country.

\section{Foreign Investment}

Since 1990 during the transition period from centrally planned economy to market economy, Mongolia has adopted several important laws promoting private sector development and foreign investment.

The main purpose of the laws to promote foreign investment, to protect rights and capital of foreign investor, to regulate the activity of joint venture Company with foreign investment.

Foreign investors have rights to invest in any sectors of economy in the territory of Mongolia not prohibited by law, to register their companies, to rent the land, to receive and transfer a dividend. Besides these, laws protect foreign capital from nationalization and illegal confiscation. 
These laws being effective have increased foreign investment to Mongolia significantly.

Today 1252 companies with foreign investment with paid-in-capital of US\$350.4 million have been registered from 60 countries.

Companies with capital from China, Japan, Korea, USA, and Russia have the leading position.

From the total foreign investment $21 \%$ has been made to geological exploration and mining sector, $12 \%$ - to textile industry, $11 \%$ - to processing livestock products, $9 \%$ - to science and education, $8 \%$ - to construction sector, $6 \%$ - to telecommunication, $4 \%$ - to tourism.

216 companies with Russian capital have invested US\$ 16.0 million to geological exploration and mining sector, feasibility studies, construction, foodstuff production and energy sector.

Also foreign corporations from USA, Hungary, Australian "Caterpillar" Korean "Samsung", "Daewoo", Japanese "Sumitomo", "Itochu" have invested in mining, telecommunication and service sectors.

Japanese "Itochu", American "Amicable Industries Inc.", "Forte Cashmere Inc.", Italian "Lori Piano C. \& Spa." have invested in cashmere processing industry.

Capitals from Korea, Taiwan, China, and Hong-Kong have been invested mainly in sewing industry. Russian and Chinese capitals have been invested in construction sector.

American oil company "Soco Nescor Energy" has invested in oil extraction fields.

Japanese "KDD", "Sumitomo", Korean "Korea Telecom” companies have invested in telecommunication.

Law on foreign investment and income tax system grants the following income tax preferences to a business entity with foreign investment:

® Power and thermal plants and transmission network thereof, highways, railways, airway and engineering constructions, basic network of telecommunications - 10 years of tax exemption and $50 \%$ tax relief in the subsequent 5 year period;

( Mining and processing of mineral resources (except precious metals), oil and coal, metallurgy, chemical production, machinery, electronics - 5 years of tax exemption and 50\% tax relief in the subsequent 5 year period;

(B) Should a business entity with foreign investment in the area other than mentioned above, exports more than 50 percent of its production, then it will 
receive tax exemption for 3 years and 50\% tax relief in the subsequent 3 year period;

( $)$ A business entity with foreign investment not referred here may be granted income tax preferences. Decision on this matter will be adopted by the State Great Hural in each case upon its presentation by the Government of Mongolia.

Foreign investors have the following rights:

- A business entity with foreign investment can have area rights according to rent agreement to use the land for period not more than 60 years, in case of prolongation based on the old agreement, the period can be prolonged for more 40 years only one time.

- A business entity with foreign investment can solve all disputes according to Law of Mongolia.

The priority sectors to attract foreign investment are:

\section{Mining Industry}

During 1992-1997 this industry produced 30\% of GDP and mining products reached $65.5 \%$ of the export of the country.

Mongolia is rich of coal, copper, gold, uranium, fluorspar, tin, molybdenum, phosphate and oil.

Today there are 100 gold deposits. Gold resources' estimate is about 157 tons.

Copper deposit is Erdenet-Ovoo, Tsagaansuvarga, estimated resources of copper - 8 million tons, molybdenum - 240 thousand tons.

Today annual production of coal from 20 mining's is 4 million tons, geological exploration works are being started in 300 deposits, coal resources amount to 125 billion tons.

There are 22 oil-extracting fields, of which 13 are drilled under contracts by companies from USA, UK, Canada and Australia.

\section{Agriculture}

This sector produces products of livestock and cereals.

Farming is being introduced.

There are 315 thousand hectares of barley and wheat plantation and 9700 hectares of vegetable plantation.

Mongolia produces $20 \%$ of world cashmere production.

Mongolia exports processed hides and skins, wool, cashmere and meat. 


\section{Tourism}

At the beginning of development, this sector had only 2 hotels in Ulaanbaatar and 3 tourist camps in the countryside.

250 companies were registered to handle tourism activities in 1999. 15 provinces have 63 tourist camps with capacity of receiving 4166 tourists and 87 hotels with 5000 bed rooms available for foreign and local visitors.

Last two years Mongolian tourism industry contributed 3\% to the growth of GDP and earnings were equivalent to $5 \%$ of export of the country.

In 1999, 158743 visitors from 125 countries visited Mongolia of which 34049 tourists on leisure tourist programmed. According to studies made by Japanese "JICA" agency the annual growth rate of tourists is $13 \%$, if this rate is sustained then in 2005 tourists visiting Mongolia will reach 75000 .

Based on current data mostly private tourism companies have been established in this sector and have good prospects for further development.

The Government of Mongolia in order to promote tourism and set up a legal framework has prepared "Master Plan" and established a National Tourism Center.

As from statistical data, majority of tourists come from Japan and the rest is from Europe, USA and other countries.

\section{A new market}

Negotiations between China and Russia are going on to explore and use Kovictynsk oil field to transport oil through territory of Mongolia and China up to Yellow sea port. This oil pipe line through our territory will have a political and economical importance. Construction of this pipe line will create working places for Mongolians, along with this pipe line, infrastructure will develop, we will receive transportation fee, there will be a possibility to use and process cheap oil, it is necessary to set up a legal framework for transportation of oil and to educate and train people in this field.

\section{Loans and assistance}

Loans and assistance provided at the Government level from foreign countries and international institutions for our economy and social development are named as "Official Development Assistance".

Loans and assistance from World Bank, Asian Development Bank, International Monetary Fund have been also included under this category. 
Since 1991 under initiatives of the Government of Japan together with World Bank "Tokyo meeting" of donor countries supporting Mongolia has been held 6 times accumulating loans and assistance for total amount of US\$1.6 billion.

US\$ 1 billion has been used in energy sector, infrastructure, and agriculture and in manufacturing sector.

At the seventh meeting of donor countries which was held in Mongolia in June 1999, US\$320 million was pledged as loans and assistance to Mongolia.

Today there are 30 countries and 10 international institutions supporting our development policy and providing loans and assistance among which Japan, Asian Development Bank, World Bank and Germany are the main donor countries.

Since 1991 the disbursement of foreign loans and assistance can be divided by stages as following:

7" stage covers the period of 1990 to 1993

Loans and assistance were used to eliminate food shortages, shortage of electricity supply, to overcome winter problems and to cover deficit of trade balance.

$2^{\text {nd }}$ stage covers the period of 1994 to 1995

Loans and assistance were provided for a medium term projects, for modernization manufacturing equipments, to reequip small and medium sized enterprises and for carrying feasibility studies.

\section{$\underline{3}^{r d}$ stage covers the period from 1996}

Loans and assistance were given for improvement of banking sector, road and railway projects, mining projects, mainly for development of infrastructure for long-term period.

Long-term loans from IMF and World Bank have low interest; payment of interest starts in 10 years at the level of $1 \%$ per annum and in the subsequent 20 years, the annual interest rate is $2 \%$

These preferential conditions of loans have been vital to our country.

From the estimated US\$ 164 million World Bank ten projects actual implementation cost amounted to US\$ 114 million. Annual project loans' amount reached US\$25-30 million.

Supporting the development of Mongolia World Bank assistance strategy is aimed to reach macroeconomic stabilization, to make structural changes in financial and manufacturing sectors, to create working places, to improve infrastructure and to eliminate poverty. 
Since Mongolian membership in Asian Development Bank in 1991, the Bank has been increasing their activity in our country.

Asian Development Bank has a second position after Japan providing loans and assistance to Mongolia.

By December 31, 1997 Asian Development Bank has disbursed total US\$ 377.5 million for financing 19 projects mainly for improvement of infrastructure. All loans were provided from Asian Development Fund.

In the mid period of 1990's Asian Development Bank disbursed annually loans amounting to US\$ 60-65 million.

$29 \%$ of loans were given to transport and telecommunication sector, $26 \%$ - to financial and manufacturing sector, $25 \%$ - to energy sector, $10 \%$ - to agriculture and $10 \%$ - to social sector.

By December 31, 1997 Asian Development Bank has disbursed for technical assistance projects total US\$38.1 million. Technical assistance was aimed to improve management, for making policy of institutional changes, creating legal framework, improving human resources and for making investment feasibility studies.

During the transition period loans from Asian Development Bank were vital and effective to overcome the problems in energy, transport and telecommunication sectors. For example, loans for financing import (1991, US\$ 30 million), project loans for manufacturing sector (1993, US\$30 million), airport project loans (1993, US\$ 36 million), loans for Ulaanbaatar, Erdent, Darkhan telecommunication network (1994, US\$25 million), loans for energy project (1994, US\$ 40 million).

In the resent years Asian Development Bank has contributed a lot to human development. Assistance was given to agriculture, education, health, and transport and energy sector. For example, US\$ 15.9 million was provided to improve health sector, for medical health care projects, family planning project and for education of human resources in this sector.

International Monetary Fund provides loans on guarantee of effective use of loans and due repayment of them.

IMF loans were given to reach macroeconomic stabilization and to eliminate obstacles to economic growth.

IMF programmers with Mongolian Government in 1992 and ESAF in 1993 had contributed significantly to Mongolian economy in transition period.

As a result of implementation of these programmers, inflation rate declined from $325.5 \%$ in 1992 to $183 \%$ in 1993 and to $66.3 \%$ in 1994 . 
Such decline of inflation created conditions to revive the economy, to stimulate manufacturing and to improve the living conditions of Mongolians.

In order to pass the transition period and to reach economic growth it is necessary to accumulate savings as the source of development and savings should be accumulated locally.

Economic prosperity can by achieved if growth of manufacturing and savings is secured.

Country will never reach economic prosperity by exporting only raw materials. It is necessary to set up processing facilities in real sectors of economy.

On the basis of scientific and technical achievements, we should develop the comparative advantages of Mongolian economy to reach economic development and prosperity.

Mongolia needs a new industrial policy to be implemented giving the priority to export - oriented and import-substitution enterprises.

\section{Recommendations for consideration}

1. To centralize and set up a new Government institution to handle foreign investment and loans, assistance issues, to define the structure, rights and responsibilities and to monitor and control the disbursement and use of loans and assistance.

2. To attract foreign direct investment to manufacturing and agriculture sectors.

3. To develop export-oriented and import-substitution enterprises. 